\title{
METHICILIN-RESISTANT STAPHYLOCOCCUS AUREUS (MRSA) AT JOS UNIVERSITY TEACHING HOSPITAL.
}

\author{
E.I. IKEH, Department of Medical Microbiology, Faculty of Medical Sciences, \\ University of Jos, P.M.B 2084 Jos, Nigeria. \\ KEY WORDS: MRSA, PREVALENCE, SUSCEPTIBILITY, ANTIBIOTICS.
}

\begin{abstract}
A prospective surveillance of Methicillin resistant staphylococcus aureus (MRSA) was carried out at Jos University Teaching Hospital, Nigeria, over a one year period. This study highlights the continuos importance of MRSA in çausing both hospital and to a less extent community acquired infections. Out of the 180 consecutive isolates of S. aureus tested, 758 (43\%) were found to be methicillin resistant, $81 \%$ (63 isolates) of the MRSA were from hospital in-patients while 19\% (15 isolates) were from out-patients. The highest rate of methicillin resistance $(81 \%)$ was found in surgical wound infections while the special care baby unity (SCBU) service recorded $4 \% .85 \%$ of the MRSA were sensitive to Ofloxacilin while $46 \%$ were sensitive to peflacine. Most MRSA isolates were multiply resistant to Augumentin, centriaxone and ceftazidime, thus confirming the nosocomial nature of the isolates. Vancomycin and teicoplanin are not locally available and so ofloxacillin is the drug of choice. This study has demonstrated a high prevalence of MRSA in our hospital, which definitely plays a significant role in hospital acquired inflections. In conclusion, the relatively high prevalence of MRSA in this study has shown that there is a "limited" level of infection control activity in our hospital.
\end{abstract}

\section{INTRODUCTION}

Hospital infections are all those infections acquired in hospital, which were absent at the admission. A few of the patients become infected with some consequences for them such as complications and prolongation of hospital stay, for their comminutes such as diffusion of infection, and for the hospital as loss of time and resources because of the use of higher quantities of antibiotics. Staphylococcus aureus is a ubiquitous organism which is present in the anterior nares of approximately $40 \%$ of healthy adults is mainly transmitted by hand contact (1), and is frequently implicated in nosocomial infections. The most remarkable feature of S. aureus, however, is its ability to acquire resistance to antibiotics. Many resistance genes are acquired by plasmid-mediated gene transfer, and some may be transferred to the chromosome as mobile genetic elements (2). Probably, the most significant achievement of S. aureus has been the acquisition of methicillin resistance. Emergence of MRSA made clinical use of vancomycin inevitable, and predisposed S. aureus towards acquisition of Glycopeptide resistance. MRSAis a generie term for all S.aureus strains carrying Mef. A gene $(3,4)$ and expressing certain levels of methicillin or oxacillin resistance.

\section{MATERIALS AND METHODS}

\section{(a) Study Area}

Jos University Teaching Hospital (JUTH) is a 521-bed tertiary hospital with acute, general and specialist units for both paediatric and adult patients. It also serves as a referral hospital.

\section{(b) Method}

The susceptibility of consecutive isolates of S.aureus (isolated within a 12 month period) to Oxacillin was determined on Mueller- Hinton agar supplemented with $2 \%$ Nacl. Plates were inoculated by dipping sterile cotton swabs into the suspension of the overnight growth of the organism prepared to a delnsity of a McFarland No.0.5 standard; expressed excess liquid from the swabs and inoculated the surface of the agar by the spread method. The 1 microgram Oxacillin discs were aseptically placed on the surface of the inoculated plates and incubated aerobically at $35^{\circ} \mathrm{C}$ for $18-24$ hours. The isolates were also similarly 
inoculated onto the surfaces of plain Mueller Hinton agar plates and Augumentin (30 $\mathrm{mcg}), \quad$ Ofloxacin (10 mcg), Pefloxacine (5mcg) and Ceftazidime $(30 \mathrm{mcg})$ discs were placed and incubated as above. The zones of inhibition were measured and compared with NCCLS (5). The isolates that were resistant to Oxacillin $(<10 \mathrm{~mm}$ diameter) were termed methicillin Resistant S.aureus (MRSA) (5).

\section{RESULTS}

This study describes a 12month audit of MRSA at JUTH. Out of 180 isolates of S.aureus tested, 78 $(43 \%)$ were found to be methicillin resistant. The MRSA accounted for $66 \%$ (57 isolates) of S.aureus from hospital in-patients and $23 \%$ (21 isolates) of those from out-patients. The percentage distribution on each service in the hospital for MRSA are shown in Table 1. Surgical services had the highest prevalence of $46 \%$, while general out-patient department (GOPD), medical, paediatric, Special Care Baby Unit (SCBU) and casualty wards had $15 \%, 12 \%, 19 \%, 4 \%$ and $4 \%$ respectively $(\mathrm{P}<0.05)$.
Table 2 shows the percentage distribution of isolated MRSA from each site of infection. Surgical wound infection recorded the highest with $81 \%$ while cutaneous, urinary tract and eye infections recorded $8 \%, 8 \%$ and $4 \%$ respectively. $(\mathrm{P}<0.05)$.

The susceptibility pattern of the 180 S.aureus isolates to Oxacillin and five other antibiotics is shown in Table $3.57 \%$ of the isolates were sensitive to Oxacillin while 43\% were resistant (MRSA). For Augumentin, $40 \%$ were sensitive while $92 \%, 12 \%, 76 \%$ and $10 \%$ of the isolates were sensitive to Ofloxacin, Ceftriaxone, pefloxacine and Ceftazidime respectively.

The susceptibility pattern of the 78 MRSA isolates are shown in Table $4.85 \%$ of them were sensitive to Ofloxacin while $46 \%$ were sensitive to Pefloxacine. The percentage sensitivities to Augumentin, Ceftriaxone and Ceftazidime were 9,6 and 7 respectively. The percentage sensitivities for the non-MRSA were as follows:-

Augumentin (64), Ofloxacin (100), ceftriaxone (9) and ceftazidime (6). Most MRSA isolates were multiply resistant to Augumentin, Ceftriaxone and Ceftazidime, thus confirming the nosocomial nature of the isulates.

TABLE 1: THE PERCENTAGE DISTRIBUTION ON EACH SERVICE FOR MRSA AT JOS UNIVERSITY TEACHING HOSPITAL, NIGERIA.

\begin{tabular}{|l|l|l|l|l|l|l|l|}
\hline Service & GOPD & CAS & MED. & SURG & PAED. & SCBU & TOTAL \\
\hline Number positive & 12 & 3 & 9 & 36 & 15 & 3 & 78 \\
\hline$\%$ Positive & 15 & 4 & 12 & 46 & 19 & 4 & 43 \\
\hline
\end{tabular}

\section{SYMBOLS}

$\begin{array}{lll}\text { GOPD } & = & \text { General Out-patient Department } \\ \text { CAS } & = & \text { Casualty } \\ \text { MED } & = & \text { Medicine } \\ \text { SURG. } & = & \text { Surgery } \\ \text { PAED } & = & \text { Paediatrics } \\ \text { SCBU } & = & \text { Special Care Baby Unit. }\end{array}$


TABL焉 2:

THE PERCENTAGE DISTREUTION OF ISOLATED MTSA FROM EACH SITE OF INECTION AT NUTH

\begin{tabular}{|l|l|l|l|l|l|}
\hline & Pathogen & \multicolumn{4}{|c|}{ Site \% } \\
\hline Isolates & MRSA & SWI & CUT. & UTI & EYE \\
\hline & \% Distribution & 81 & 8 & 8 & 4 \\
\hline & Number & 63 & 6 & 6 & 3 \\
\hline
\end{tabular}

\section{SYMBOLS}

SWI

$=\quad$ Surgical Wound Infection

CUT

= Cutaneous

UTI

$=\quad$ Urinary Tract Infection

EYE

$=$ Eye

TABLE 3: PERCNTAGE SENSITIVTTES OF 180 2. aMreu ISOLATES TO METHCHLIN AND 5 OTHER ANTIEIOTHCS AF JUTH, NGERE.

\begin{tabular}{|c|c|c|c|c|c|c|c|c|c|c|c|}
\hline \multicolumn{2}{|c|}{ Antibiotic $=$ Methicillin } & \multicolumn{2}{|c|}{ Augumentin } & \multicolumn{2}{|c|}{ Onoxacin } & & \multicolumn{2}{|c|}{ Fefloxacin } & \multicolumn{2}{|c|}{ Ceftazidime } \\
\hline \multirow{2}{*}{$\begin{array}{c}\text { Sensitive } \\
57\end{array}$} & \multirow{2}{*}{$\begin{array}{c}\text { Resistant } \\
43\end{array}$} & \multirow{2}{*}{\multicolumn{2}{|c|}{ 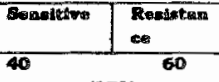 }} & \multicolumn{2}{|l|}{ Senwitive } & 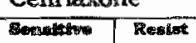 & $\begin{array}{l}\text { Restivet } \\
\text { ences }\end{array}$ & Seanation & Renotert & Borantion & \multirow{2}{*}{$\begin{aligned} \begin{array}{c}\text { Renita } \\
\text { ence }\end{array} \\
90\end{aligned}$} \\
\hline & & & & $\mathbf{9 2}$ & & & & 76 & 24 & 10 & \\
\hline
\end{tabular}

Figures in parenthesis indicate the number of isolates tested, whenever these were less than the number isolated.

TABLE 4: PERCENTAGE SENSITIVITIES OF MRSA AND NON-MRSA ISOLATES TO 5 ANTIBIOTHCS AT JUTH, MIGERIA.

\begin{tabular}{|c|c|c|c|c|c|c|c|c|c|c|}
\hline \multirow{3}{*}{$\begin{array}{l}\text { Antibiotic MRSA, } \\
n=78 \\
\text { Non-MRSA, } n=102\end{array}$} & \multicolumn{2}{|c|}{ Augumentin } & \multicolumn{2}{|c|}{ Ofloxacin } & \multicolumn{2}{|c|}{ Cenriaxone } & \multicolumn{2}{|c|}{ Pefloxacin } & \multicolumn{2}{|c|}{ Ceftazidimé } \\
\hline & Sensitivr & Res:sistatition & Serextitive & Fuswotiance & Strisition & $\begin{array}{l}\text { Rewisiti } \\
\text { waxe }\end{array}$ & Sersilite & Refiate & sensitive & $\begin{array}{l}\text { Resisistm } \\
\text { (x) }\end{array}$ \\
\hline & & $\begin{array}{l}91 \\
36\end{array}$ & $\begin{array}{l}85 \\
100\end{array}$ & & $\begin{array}{l}6 \\
9\end{array}$ & & & & & \\
\hline
\end{tabular}

$$
\mathrm{X}^{2}=157.69 ; \quad \mathrm{P}<0.05
$$

Figures in parenthesis indicate the number of isolates tested, whenever these were less than the number isolated. 


\section{DISCUSSION}

The study has highlighted the continuous importance of MRSA in causing both hospital and to a less extent community acquired infections. The relatively high prevalence $(43 \%)$ of MRSA has shown that there is a "limited" level of infection control activity at JUTH. This must have accounted for the high prevalence of post-operative wound infections earlier reported by Ihezue et al (6) in the hospital. The highest prevalence of $46 \%$ in surgical services is attributed to the lack of adequate precautions in the surgical wards especially with respect to wound dressing. The low prevalence of $4 \%$ MRSA in SCBU is due to the increased awareness amongst the SCBU staff of the need to prevent nosocomial infection in that unit. It has been found out that control and surveillance of nosocomial infection does not have a priority at senior management levels withir the hospital. Thus immediate infection control measures with emphasis on vigilant and careful handwashing before and after patient contact, strict isolation measures, culture surveillance, interhospital transfer policies and in-service education will ultimately reduce the incidence of nosocomial MRSA in our hospital. A very effective infection control committee in the hospital will help to co-ordinate the above measures as the costs of an MRSA outbreak both financially and psychologically cannot be overemphasized. In the absence of the glycopeptides (vancomycin and teicoplanin) in Nigeria, Ofloxacin and to a lesser extent pefloxacin are the antibiotics of choice for the treatment of MRSA infections in our local setting. In order to preserve the efficacy of these two drugs the following interventions should be implemented:- (a) prospective. identification of patients at risk (risk profilling); (b) institution of proven preventive strategies; (c) rapid identification of infection sources in high risk individuals (d) monitoring the prevalence of antimicrobial resistance for individual pathogens and (e) appropriate selection of antibiotics and adjunctive therapy.

\section{REFRRENCE}

1. Edmund M.B, Paxculle, A.W. Vancomycin- resistant staphylococcus aureus: perspectives on measures needed for control. Annals of Int. Med. 1996; 124:329- 334

2. Lyon, B., Skurray, R. Antimicrobial resistance of staphylococcus aureus: genetic basis. Microbial reviews 1987; 51:88-134.

3. Matsuhashi, M., Song M.D. Ishine, F. ot. al molecular Cloning of the gene of a pencillin- binding protein supposed to cause high resistance to betalactam antibiotics in Staphylococcus aureus. Journal of Bacteriology 1986; 167: 975-980.

4. Song, M.D., Wachi, M; Doi, M. et al. Evolution of an inducible penicillin-target protein in methicillin -, resistant Staphylococcus aureus by gene fusion. FEBS Letter 1987; 221:167-171.

5. NCCLS. Performance standards for antimicrobial susceptibility testing, sixth informational supplement. NCCLS document M100-56, 1995.

6. Thezue, C. H., Ikeh, E.I., Ugwuegbulem, S.C. et al; Incidence of wound Infections on the Surgical Services: A Nigerian Experience. New York Infect. Med $12(2) ; 83-86,1995$ 